\title{
Kvalitatív Komparatív Analízis a pedagógiai térábrázolásban
}

A tanulmány a pedagógiai terek vizsgálata során empirikus környezetben mutatja be a Kvalitativ Komparativ Analizis (Qualitative Comparative Analysis) csQCA (Crisp-Set QCA) változatát, továbbá a kötetlen reflektív napló, a csQCA és a $M A X Q D A$ alkalmazásával megvalósított számítógéppel támogatott kvalitatív adatelemzés közötti kapcsolati rendszert illusztrálja. A kapcsolati háló kiépitése során a tanulmány figyelmet fordit a topologikus fordulat neveléstudomány számára releváns aspektusaira is.

\begin{abstract}
A z 1980-as évek végén Edward Soja által bevezetett topologikus vagy térbeli fordulat ('spatial turn') teoretikus és módszertani értelemben is alapvető változásokat generált a társadalomtudományi kutatások szemléletében. Minderre bizonyíték, hogy az elmúlt évtizedekben a tér vizsgálatok és elméleti értekezések központi elemévé vált (Döring és Thielemann, 2008; Stefer, 2011).

Jelen tanulmányban a térbeli fordulat neveléstudomány számára releváns aspektusaira fókuszálunk. Hangsúlyozzuk a pedagógiai terek jelentőségét a tanítás-tanulás folyamatában, valamint hallgatói nézetek alapján vizsgáljuk a pedagógiai terek és a didaktikai elemek, tanítási módszerek összefüggéseit. A kutatás módszertani hátterét napjaink társadalomtudományi kutatásmódszertani világának egyik releváns eleme, a Kvalitatív Komparatív Analízis (Qualitative Comparative Analysis, QCA) biztosítja. A QCA-technika elméleti vonatkozásainak hazai ismertetése után (Sántha, 2014) további célunk a módszer empirikus kutatásban való illusztrálása is. Ezzel pedig reményeink szerint a módszert kézzelfoghatóvá tesszük a hazai neveléstudományi vizsgálatok számára is.
\end{abstract}

\section{A térbeli fordulat általános jellemzőitől a neveléstudományi vonatkozásokig}

A térbeli fordulat perspektívaváltást helyezett előtérbe: felhívta a figyelmet arra, hogy a modern társadalomtudományi kutatások világában megoldást kell találni a térfeledés problémájára, vagyis az idő kategóriájának térrel szembeni előtérbe helyezésére. A térbeli fordulat elsősorban a társadalmilag létrehozott térre figyelt, mégis, az elmúlt évtizedekben a különféle tudományterületekre gyakorolt hatása vitathatatlan. Verd és Porcel (2012) hangsúlyozzák, hogy a tér a társadalmi folyamatok, jelenségek vizsgálatának kereteit biztosítja. A térbeli fordulat következményeként megjelenő téri információk a kvalitatív társadalomtudományi kutatások fókuszába helyezték a Goodchild és munkatársai (2000) által használt 'területileg integrált társadalomtudomány' (Spatially Integrated Social Science [Bővebben lásd a Center for Spatially Integrated Social Science honlapját: www.CSISS.org]) fogalmát, ahol központi elemként jelenik meg a térbeli jelenségek, a téri adatok vizualizációja és elemzése, továbbá lehetővé válik a szociá- 
lis, társadalmi rendszerek térbeli és időbeli kontextusban való szimulációja is (Cisneros Puebla, 2008).

A térről való gondolkodás ma már szerteágazó, a probléma interdiszciplináris jellegének köszönhetően tértipológiák sokaságát ismerjük. Ezt támasztja alá a tér fizikai (topológiai, projektív, lineáris és körkörös), metafizikai (mitikus, szakrális), társadalmi (szociológiai, nemzeti-történeti, lokális, globális), kommunikatív (nyelvi, textuális, kontextuális, narratív, hermeneutikai) értelemben történő vizsgálata is (A tér diskurzusai..., é. n.; Sántha, 2012). E sokoldalú térértelmezés mellett Yates (2010) további tértipológiákat ismertet, a teljesség igénye nélkül például az euklideszi, nem euklideszi - hiperbolikus, koreografikus, metrikus, topologikus, abszolút, relatív, véges, végtelen térértelmezéseket. Yates felveti azt is, hogy a tér érzékszerveink útján tapasztalt realitás lenne.

Ezekkel az elképzelésekkel részben rokon vonásokat hordoz, részben pedig más kontextusbeli megvilágítást tesz lehetővé Lefebvre (2006) trialektikus térkoncepciója. Az érzékelt, észlelt tér ('perceived space') a tér fizikai szinten történő vizsgálatát teszi lehetővé. Az elgondolt, elképzelt tér ('conceived space') a mentális, kognitív szinten megjelenő tér elemzését segíti, míg a megélt tér ('lived space') a szociális szinten feltünő tér sokoldalú megközelítését szorgalmazza. A teret magunk hozzuk létre, így minden társadalom saját térbeliséggel rendelkezik (Lefebvre, 2006).

A tér vizsgálatának gazdag eszköztárában kvantitatív és kvalitatív technikák is találhatók. A téri elemzések interdiszciplináris jellegét mi sem bizonyítja jobban, mint hogy a földrajz, a matematika, a közgazdaságtan mellett a pszichológia is releváns információkat hordozhat a tér vizsgálatával foglalkozó szakemberek számára. Ebből a sokrétüségből profitálhat a neveléstudomány is. Poreisz (2013) az objektív és szubjektív térérzékelés elemzésének módszertani hátterét vizsgáló tanulmányában kiemeli, hogy az objektív (fizikai, épített) környezet és az egyén által érzékelt szubjektív tér közötti eltérések okai a percepcióban, az érzékelésben keresendők. Különböző személyek eltérően érzékelik a körülöttük lévő környezetet, így az információk feldolgozásához is másként látnak hozzá. Ezek releváns gondolatok a kvalitatív pedagógiai kutatásmódszertan számára is, hiszen a téri információk kezelésénél nem tagadják a szubjektivitás létezését.

A téri információk értelmezése a társadalomtudományokban az 1990-es évek végére, a 2000-es évek elejére újabb megvilágításba került. Napvilágot láttak olyan elképzelések, amelyek a tér mellett más tényezők szerepét is kiemelten fontosnak vélték a társadalmi valóság formálásában és vizsgálatában. A tér és idő viszonyának Paul Virilio-féle értelmezésén túl (a tér az idő alárendeltjévé válik), egyre inkább központi figyelem illeti a Manuel Castells (2005) által bevezetett 'hálózati társadalom' fogalmát. Castells felhívja a figyelmet arra, hogy információs korunkban a terek helyett célszerübb lenne a hálózatok vizsgálatára koncentrálni, hiszen a társadalom és a gazdaság kapcsolati rendszere, müködése csak ezek segítségével érthető meg és tárható fel. A komplex hálózatok főbb kutatási kérdéseibe bepillantást nyerhetünk Barabási (2008, 2011) köteteiből, amelyek a matematikai ismeretekkel nem rendelkező olvasó számára is kitünő olvasmányt jelenthetnek. E problémakör neveléstudományi relevanciáit elökészítette a Galois-gráfokról, hálókról szóló munka (Takács, 2000), továbbá újabban a tudástérelmélet problémakörének vizsgálata is alapoz erre (Tóth, 2012). A neveléstudomány számára szintén releváns információkkal bír Pléh (2014) az ént körülvevő hálózatokkal kapcsolatos tanulmánya is, hiszen rámutat az Én-központú hálózatkutatás technikai újításaira is.

A testi tér és a szellemi tér vizsgálata, valamint a tér szerkezetének emberre gyakorolt hatásainak elemzési lehetőségei rejlenek Sánta (é. n.) írásában, aki többek között a térre vonatkozó olyan komplex matematikai, fizikai, kommunikációbeli problémákat közöl, melyek továbbgondolása a neveléstudomány, a pedagógiai térszervezés számára is értékes megállapításokhoz vezethet. Továbbá a pedagógiai terek minőségi dimenzióinak (Sanda , 2012) értelmezése és részletes tárgyalása szintén tisztázhatja a neveléstudomány 
számára releváns térmegközelítéseket. Ezt azért állíthatjuk, mert a szerteágazó térkoncepciók sokaságában a neveléstudomány számára sokszor nehéz kijelölni azt az utat, amelyet végigjárva eredményes tanítási-tanulási folyamat generálható. Állításunk azonnal vitát is eredményezhet: Van ilyen út? Ki kell, ki lehet jelölni ilyen utat, vagy a különféle úthálózatokat használva jutunk el a hatékony iskolai tanítási-tanulási folyamathoz?

Mivel a tér fogalma nem egységesen definiált, a különböző tudományterületek eltérően értelmezik: a társadalmi tér vagy a hiperbolikus tér más definíciós háttéren alapul, más aspektusból való vizsgálatot feltételez és tesz lehetővé. Így állíthatjuk, hogy nincs egységes módja a tér vizsgálatának. Azonnal adódik a következő kérdés is: szükséges-e mindenképpen egységes térvizsgálatot keresni? Érdekes problémakör ez főleg abban a tekintetben, hogy a számítógéppel támogatott kvalitatív adatelemzés során a multikódolt adatok (szöveg, kép, audio- és videoadat) vizsgálatára alkalmas újabb szoftverek funkciói kitűnően alkalmazhatók például földrajzi, szociológiai vagy akár pedagógiai projektekben is. Ma már a térinformatikai elemek (geo-információk) kvalitatív pedagógiai vizsgálatokba történő beemelésének lehetősége a kvalitatív adatelemzésre alkalmas szoftverek részét képezi, megjelennek például az ATLAS.ti ${ }^{\mathrm{TM}}$, a MAXQDA ${ }^{\mathrm{TM}}$ vagy az NVivo $^{\text {TM }}$ funkciói között is (Sántha, 2012, 2013). A komplex térértelmezési lehetőségek alapján arra következtethetünk, hogy a számítógéppel támogatott kvalitatív adatelemzés során a modern szoftverek elsősorban a tér fizikai értelmezését teszik lehetővé, továbbá segítségükkel bepillantást nyerhetünk a társadalmi, szociális szinten feltünő térértelmezés kérdéseibe is.

A számítógéppel támogatott kvalitatív adatelemzés mellett az utóbbi években a nemzetközi és a hazai neveléstudományi szakirodalom is figyelemmel kíséri a pedagógiai tér, az iskolai térszervezés problematikáját és az általa generált didaktikai aspektusok elemzését, valamint a pedagógiai architektúrának az iskolai élet föszereplöire gyakorolt hatását (Hercz és Sántha, 2009; Jelich és Kemnitz, 2003; Kemnitz, 2003). A térhatások elemzése során indokolt figyelemmel kísérni azt, hogy a tér miként befolyásolja a pedagógusok és a tanulók viselkedését; milyen összefüggések léteznek a tér és az emberi viselkedés, életmód között; az intézmény biztosítja-e az egyéni tér, a közösségi tér kialakításának lehetőségét, hiszen mindezek kiemelt paraméterei a tanulási tér kialakulásának (Hercz és Sántha, 2009). A tér, a viselkedés, az életmód közötti összefüggések feltárásánál a biológia tudománya is segítségünkre lehet a téri információkkal karöltve: az életközösségekhez számos ökológiai környezet rendelhető hozzá, a közösség elemeire ugyanabban az időpontban más és más környezet hat. Mindezt a neveléstudomány témaköreire konvertálva, például a tanulók tanulmányi teljesítményének elemzésekor célszerü figyelembe venni a különböző mikro- és makro környezeti hatásokat is, hiszen mindezek jelentősen hatnak az életmódra és így a tanulmányi teljesítményre is. A kérdést továbbgondolva igaz ez a különböző földrajzi egységekben élők viselkedésének, szokásainak feltárásakor is.

A pedagógiai tér a történeti jellegü vizsgálatokban is helyet kapott. Géczi (2010) a térszimbolizáció megjelenését vizsgálta a korabeli magyar pedagógiai szaksajtóban. Elemzésének fókuszában eltérő hangsúllyal ugyan, de megtalálható a három antropológiai tér. Az első antropológiai tér elemeit egy adott képen látható személyek testfelülete, ruházata, hajviselete stb. alkotja, a másodikat az a közvetlen környezet képviseli, amelyben az első tér megtalálható, míg a harmadik antropológiai tér a képen látható személyek életének terét jelenti. Utóbbi az előző tereknél bővebb kiterjesztésű, hiszen az élet eseményeinek színterét mutatja.

A pedagógiai tér kérdésének új perspektívából való megvilágítását tükrözik azok a vizsgálatok, amelyek a modern kor elemeit, például a Facebook-jelenséget hozzák összefüggésbe a személyes és szocializációs térrel, valamint a tanulás színterével (Kárpáti, Szálas és Kuttner, 2012). A virtuális környezetek oktatásban való megjelenése ma már a 
mindennapok pedagógiai világának részét képezhetik (Ollé, 2012). A virtuális világban kommunikálva lehetőség nyílik együttmüködésre, különböző projektekben való részvételre. A virtuális világot jellemző tájékozódást, az azt müködtető mechanizmusokat kitűnően ábrázolja Ollé (2012) kötete. Az új tanulási környezetek jellemzőit látva felvetődik a kérdés, hogy mindezen új térstruktúrák miként állíthatók a számítógéppel támogatott kvalitatív pedagógiai vizsgálatok fókuszába. Feltételezhetünk-e kapcsolatot a virtuális környezetek és a számítógéppel támogatott kvalitatív adatelemzés között? A válasz több szempontból is pozitív, hiszen például a virtuális környezetek különböző fázisainak képernyőrészletei pdf-fájlként menthetők, így ezek a fájlok importálhatók a kvalitatív adatelemzésre alkalmas szoftverekbe, majd képként kódolhatók és különböző elemzések, összehasonlító vizsgálatok számára is rendelkezésre állnak. Továbbá lehetőség van a virtuális környezetek képernyőrészleteit jpg-fájlként menteni és a kvalitatív pedagógiai projekten kívül tárolni. Szükség esetén ezek a fájlok a szoftverek segítségével linkként társíthatók, lásd például a MAXQDA ${ }^{\mathrm{TM}}$ szoftver funkcióit (Sántha, 2013).

\section{Módszertani háttér}

A vizsgálat módszertani háttere összetett módszertani kultúrára épül. Levelező tagozatos hallgatókat ( $\mathrm{N}=29)$ arra kértünk, hogy kötetlen reflektív napló segítségével fogalmazzák meg gondolataikat az osztálytermi térstrukturálásra vonatkozóan. Formálják olyanná a teret, ahol a tanítás-tanulás folyamatát leghatékonyabbnak vélik. A kivitelezéshez a kötetlen reflektív napló alkalmas, hiszen a fö gondolati struktúra kijelölése mellett nem szab korlátot, vagyis az egyéni, szubjektív álláspontok és a térstrukturálás kapcsolata a lehető legjobban kivitelezhetőnek tünt. A naplók adatainak feldolgozása és az adatokból történő elméletgenerálás a Kvalitatív Komparatív Analízis (Qualitative Comparative Analysis - QCA) csQCA (Crisp-set QCA) segítségével történt, míg az elméletgenerálás vizualizációját a MAXQDA szoftver MAXMaps funkciója tette lehetővé. A módszer használatához szükséges feltételek (változók) kialakításához első lépés a kötetlen reflektív naplók tartalomelemzése volt. A feltételeket (változókat) induktív tartalomelemzéssel azonosítottuk (Mayring, 2003). Az alkalmazott eljárások sémáját az 1. ábra illusztrálja.

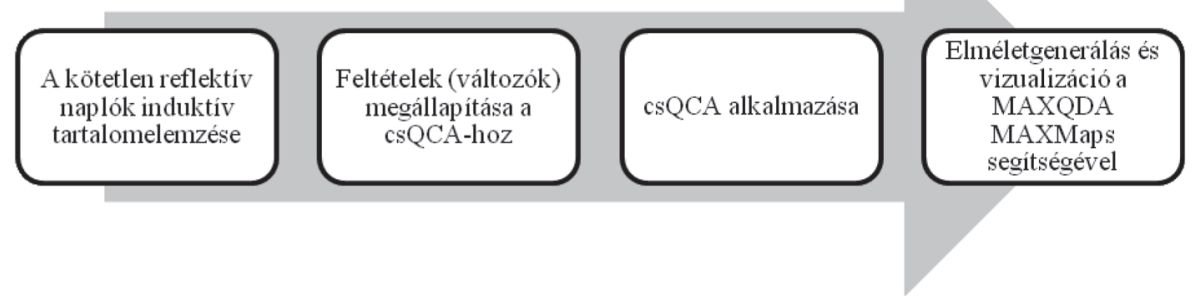

1. ábra. A vizsgálat módszertani kultúrája

A vizsgálat módszertani kultúrájának megértéséhez előbb indokolt a QCA-technika megismerése. Az ismertetést röviden és célirányosan végezzük, hiszen részletes leírás már olvasható Sántha (2014) tanulmányában. Napjainkban a QCA-t számos tudományterület, többek között az összehasonlító politikatudomány, a szociológia, a közgazdaságtudomány, a jog és a nemzetközi kapcsolatok is alkalmazza (Schneider és Wagemann, 2007; 
Wendler, Bukvova és Leupold, 2013), de a neveléstudományban történő felhasználásáról sem nemzetközi, sem hazai tekintetben nincs tudomásunk.

A QCA-technika matematikai háttérrel rendelkezik, a Boole-algebra elemeit használja. Nem sorolható egyértelmüen sem a kvalitatív, sem a kvantitatív paradigmához, de logikai alapja pozitivista jelleggel ruházza fel, míg az eredmények értelmezése az interpretatív paradigma jellemzőit hordozza. A módszer a kvalitatív esetcentrikus és a kvantitatív változócentrikus elemek összekapcsolására alkalmas, elméletek vagy hipotézisek tesztelésére használható, de lehetővé teszi új hipotézisek vagy elméletek megalkotását is (Rihoux, Rezsöhazy és Bol, 2011). E lehetőségek közül jelen tanulmányban az elméletgenerálást használtuk.

A módszer sokváltozós és kevés esetet felvonultató vizsgálatok számára ajánlott, így gyakori kérdés, hogy milyen mintaszámnál alkalmazható. A válaszok alapján többféle álláspont rajzolható ki. A közepes nagyságú mintával dolgozók számára Legewie (2013) $15<\mathrm{N}<50$, Thiem és Duşa (2013) $10 \leq \mathrm{N} \leq 30$, míg Herrmann és Cronqvist (2006) $5 \leq$ $\mathrm{N} \leq 50$ mintaszámot is elfogadhatónak tart. A tanulmányban alkalmazott mintaszám $(\mathrm{N}$ =29) alapján releváns technika a QCA.

Az utóbbi évtizedben a módszer különböző tudományterületeken való jártasságának köszönhetően egyre több követőre talált, továbbfejlődött. Napjainkban három nagy területéről beszélünk (csQCA, fsQCA, mvQCA), melyekről Sántha (2014) tanulmánya részletesen beszámolt. E területek közül röviden az ebben a tanulmányban is alkalmazott csQCA (Crisp-set QCA) részletezésére térünk ki. A csQCA a klasszikus első verzió,csak dichotomizált változókkal dolgozik, a Boole-algebrával összhangban minden lehetséges konfigurációt a 0 (nem teljesül, hamis) és az 1 (teljesül, igaz) értékekkel jellemez (Ragin, 1987). A feltételek minden logikailag lehetséges kombinációját vizsgálja annak érdekében, hogy az esetet a lehető legjobban leírja (Sántha, 2014; Schneider és Wagemann, 2007; Wendler, Bukvova és Leupold, 2013). A módszer tehát matematikai (algebrai, halmazelméleti) eljárásokra épül, alapkoncepciója különböző esetek vizsgálata. Az esetek halmazokként reprezentáltak, a változók kétértéküek: 1 , ha az adott jelenség megvalósult (igaz), illetve 0 , ha a jelenség nem valósult meg (nem igaz). A változók a feltételek nevet viselik. Az eredmények függetlenül attól, hogy a jelenség megvalósult vagy sem, kimenetként értelmezhetők.

A technika alkalmazását számos kritika érte a dichotomizálás miatt mondván, hogy a nagy információveszteség miatt redukálja a társadalmi valóság komplexitását. Az összetett világok - ilyen világként fogható fel a neveléstudomány, szükebben az iskola mindennapi pedagógiai világa is - komplexitásukból adódóan sokféle megközelítések alapján értelmezhetők, így megítélésük nem müködhet dichotomizálás alapján. Egyetérthetünk a kritikákkal annyi megjegyzés mellett, hogy a jelzett problémák kiküszöbölésére már léteznek újabb QCA-tipológiák (pl. fsQCA, mvQCA), melyek müködése nem érthető meg a csQCA jellemzőinek ismerete nélkül.

\section{Adatfeldolgozás}

A módszertani rész bevezetőjében rögzítettek szerint a csQCA alkalmazásához szükséges feltételek (változók) kialakításához első lépésben a kötetlen reflektív naplók tartalomelemzésével jutottunk el. A feltételeket (változókat) induktív tartalomelemzéssel azonosítottuk (Mayring, 2003). A szövegből külső szempontsor alkalmazása nélkül főkategóriákat kerestünk, amelyek a vizsgálat feltételeit (változóit) jelentették. Az induktív tartalomelemzéssel három feltételt, a térstrukturálást $(\mathrm{T})$, módszertani kultúrát $(\mathrm{M})$ és oktatási eszközöket (E) azonosítottunk. 
A feltételek ismeretében elkészítettük a hipotetikus igazságtáblát (1. táblázat). Az igazságtábla központi szerepet tölt be az elemzésben, koncepciója a formális logikából származik. A szükséges és elégséges feltételek lehetséges elégséges lépéseinek vizsgálatához az adatok igazságtáblázatban kerülnek megjelenítésre. A táblázat oszlopaiban a feltételek (változók) állnak, míg a sorok az eseteket mutatják. A cellákban az 1 és a 0 jelzi, hogy az adott feltétel teljesült vagy sem. Mivel a csQCA alapján minden feltételnek (változónak) két kimenetele van (0 vagy 1 ), ezért $n$ független feltételnél (változónál) $2^{n}$ lehetséges egymástól különböző konfiguráció létezik (Sager és Ledermann, 2013; Sántha, 2014; Schneider és Wagemann, 2007; Wendler, Bukvova és Leupold, 2013).

Mivel a kötetlen reflektív naplók induktív tartalomelemzése során három feltételt (változót) alakítottunk ki, ezért a hipotetikus igazságtábla nyolc lehetséges különböző konfiguráció alapján állt össze (1. táblázat).

1. táblázat. Hipotetikus igazságtábla

\begin{tabular}{|c|c|c|c|c|c|}
\hline \multirow{2}{*}{ Eset } & \multicolumn{3}{|c|}{ Feltételek (változók) } & Kimenet (változó) & \multirow{2}{*}{ N =29 } \\
\cline { 2 - 5 } & $\begin{array}{c}\text { Térstrukturálás } \\
(T)\end{array}$ & $\begin{array}{c}\text { Módszertani } \\
\text { kultúra (M) }\end{array}$ & $\begin{array}{c}\text { Oktatási } \\
\text { eszközök (E) }\end{array}$ & $\begin{array}{c}\text { Hatékony } \\
\text { tanitás-tanulás }(Y)\end{array}$ & \\
\hline 1. & 1 & 1 & 1 & 1 & 7 \\
\hline 2. & 0 & 0 & 0 & 0 & 3 \\
\hline 3. & 1 & 1 & 0 & 1 & 7 \\
\hline 4. & 1 & 0 & 0 & 1 & 7 \\
\hline 5. & 1 & 0 & 1 & 1 & 1 \\
\hline 6. & 0 & 0 & 1 & 1 & 0 \\
\hline 7. & 0 & 1 & 1 & $?$ & 0 \\
\hline 8. & 0 & 1 & 0 & $?$ & 7 \\
\hline
\end{tabular}

Az 1. táblázat az összes lehetséges variációk számát adja, melyek a valóságban nem feltétlenül jelennek meg. Így fordulhat elő az, hogy a naplókban az 1-6. esetek a megfigyelt, valós esetek, míg a 7. és 8. eseteket logikai eseteknek nevezzük, hiszen csak matematikailag igaz konfigurációk, azaz nem valóságos, ténylegesen megfigyelhető eseteken alapulnak. A vizsgálat során ellentmondásokkal nem találkoztunk, vagyis nem fordultak elő olyan esetek, amelyek azonos konfigurációval, de különböző kimenettel bírtak volna.

Ezután a hipotetikus igazságtábla eseteinek összehasonlító elemzése következett. Első lépésben azon eseteket vizsgáltuk, amelyek minden független feltételnél (változónál) ugyanazt a kimenetet eredményezték. Ehhez szükséges az összeadás és a szorzás műveletének értelmezése: egy Boole-összeg a logikai 'vagy'-ot képviseli, a szorzás pedig a feltételek kombinációját jelenti és logikai 'és'-ként értelmezhető. Minden eset Boole-szorzatként írható le, ahol a nagybetűk a feltételek (változók) teljesülését (1), míg a kisbetük a nem teljesülést (0) jelentik. A vizsgálat alapján a következő szituáció állt elő:

$\mathrm{Y}=1$ teljesülésre, megvalósulásra (MV) az 1., 3., 4., 5. és 6. esetek vonatkoztak, vagyis $\mathrm{MV}=\mathrm{TME}+\mathrm{TMe}+\mathrm{Tme}+\mathrm{TmE}+\mathrm{tmE}$. Ezt a kifejezést az $\mathrm{Y}=1$ kimenetre vonatkozó primitív kifejezésnek nevezzük.

$\mathrm{Y}=0$ nem teljesüléshez a 2. eset tartozott, azaz $\mathrm{mv}=$ tme. Utóbbi az $\mathrm{Y}=0$ kimenetre vonatkozó primitív kifejezés.

A hipotetikus igazságtábla eseteinek összehasonlító elemzésénél a második lépés a konfigurációk logikai minimalizálása (Boole-minimalizálás). Ekkor a kifejezések a kutatási célok szempontjából lényeges elemekre redukálandók. A minimalizálási folyamat lényege, hogy a módszer olyan konfigurációkat keres, amelyek egy vagy több esetet egy bizonyos kimenettel magyaráznak. Lényeges szempont, hogy a ténylegesen megfigyel- 
hető, valós esetek vethetők alá a logikai minimalizálás folyamatának. Ebben a folyamatban jelentős szerepet kap a Quine-McCluskey algoritmus, amely az elégséges feltételek elemzését teszi lehetővé. A vizsgálatban ezt az algoritmust alkalmaztuk.

A logikai minimalizálás áttekinthetősége érdekében táblázatban tüntettük fel az $\mathrm{Y}=0$ és $Y=1$ kimenetekhez tartozó primitív kifejezéseket (lásd mv és MV). Jelölje MV az Y = 1 , míg mv az $\mathrm{Y}=0$ kimenetek összegét (2. táblázat).

2. táblázat. Primitiv kifejezések

\begin{tabular}{|c|c|}
\hline Esetek & $\begin{array}{c}\text { Primitív kifejezések } \\
\text { (Feltételek kombinációja) }\end{array}$ \\
\hline $\mathrm{Y}=0$, nem teljesülés (mv): 2 . & $\mathrm{mv}=\mathrm{tme}$ \\
\hline$Y=1$, teljesülés (MV): 1, 3,4,5,6. & $\mathrm{MV}=\mathrm{TME}+\mathrm{TMe}+\mathrm{Tme}+\mathrm{TmE}+\mathrm{tmE}$ \\
\hline
\end{tabular}

Mivel csak azon konfigurációk hasonlíthatók össze, melyek azonos kimeneteket produkálnak, ezért a 0 és 1 kimenetek vizsgálata különböző úton történhet. Kutatói döntésen, a témán, a célon múlik, hogy mindkét lehetséges irányt megvizsgáljuk, vagy csak az egyik utat járjuk be. A továbbiakban az Y=1-re vonatkozó primitív kifejezéssel dolgozunk.

A konfigurációk páronkénti összehasonlításával logikai minimalizálásra, a kifejezések redukálására törekedtünk. A minimalizálás kétlépcsős folyamat (Sántha, 2014; Schneider és Wagemann, 2007; Wendler, Bukvova és Leupold, 2013):

a) szomszédos kombinációk megkeresése és páronkénti összehasonlítása,

b) prímimplikáns-tábla előállítása.

a) Szomszédos kombinációk megkeresése és összehasonlítása: két kombináció szomszédos, ha van olyan feltétel (változó), amely egyik esetben teljesül, a másiknál pedig nem, valamint a többi feltétel azonos értéken szerepel. Továbbá két kombinációban egy és csakis egy 1-es különbség lehet. Akkor értünk el a tovább nem egyszerüsíthető formulához, ha a kifejezésben egyetlen feltétel (változó, betű) sem hagyható el anélkül, hogy ne változna a kifejezés értéke. Az egyszerüsítés során a következő kijelentést használtuk: ha 'abc' és 'abC' ugyanazon kimenethez vezetnek, akkor 'ab' is ugyanazon eredményhez vezet függetlenül attól, hogy kisbetüs vagy sem, azaz megvalósult vagy sem, vagyis $\mathrm{abc}+\mathrm{abC}=\mathrm{ab}(\mathrm{c}+\mathrm{C})=\mathrm{ab}$ (Sántha, 2014).

Mindez az MV $=\mathrm{TME}+\mathrm{TMe}+\mathrm{Tme}+\mathrm{TmE}+\mathrm{tmE}$ megvalósult esetekre vonatkozó primitív kifejezésre nézve, a kifejezést páronként minimalizálva a következőket jelentette:

$$
\begin{aligned}
& (1,3): \mathrm{TME}+\mathrm{TMe}=\mathrm{TM}(\mathrm{E}+\mathrm{e})=\mathrm{TM} \\
& (1,5): \mathrm{TME}+\mathrm{TmE}=\mathrm{TE}(\mathrm{M}+\mathrm{m})=\mathrm{TE} \\
& (4,5): \mathrm{Tme}+\mathrm{TmE}=\mathrm{Tm}(\mathrm{e}+\mathrm{E})=\mathrm{Tm} \\
& (5,6): \mathrm{TmE}+\mathrm{tmE}=\mathrm{mE}(\mathrm{T}+\mathrm{t})=\mathrm{mE} \\
& (3,4): \mathrm{TMe}+\mathrm{Tme}=\mathrm{Te}(\mathrm{M}+\mathrm{m})=\mathrm{Te}
\end{aligned}
$$

Ekkor a következő redukált kifejezést kaptuk: $\mathrm{MV}=\mathrm{TM}+\mathrm{TE}+\mathrm{Tm}+\mathrm{mE}+\mathrm{Te}$. A kifejezés tovább redukálható. ezért az előbbi rendszert alkalmazva, továbbá felhasználva azt, hogy $\mathrm{T}$ v T $\rightarrow \mathrm{T}$, a következő tovább nem redukálható, minimalizált kifejezéshez jutunk: $\mathrm{MV}=\mathrm{T}+\mathrm{mE}$.

b) A minimalizálás második lépésében cél a prímimplikáns-tábla(3. táblázat) létrehozása azért, hogy végső konfigurációt találjunk Y kimenethez. A táblázat a minimalizált és az eredeti primitív kifejezéseket ábrázolja. A prímimplikáns-tábla megmutatja, hogy a primitív kifejezés (esetünkben az $\mathrm{Y}=1$ kimenetre vonatkozó primitív kifejezés) milyen prímimplikánsokkal fedhető le. A prímimplikáns-táblázat elkészítése során indokolt figyelembe venni a következő kijelentést: Egy A kifejezés meghatározza B-t, ha a 
$\mathrm{B}$ részhalmaza A-nak, azaz A implikálja B-t. Ekkor a táblázat oszlopaiba oda kerül $\mathrm{X}$, ahol a minimalizált kifejezés meghatározza a primitív kifejezést. Ennek alapján a kutatásra vonatkozó prímimplikáns-táblázat (3. táblázat):

3. táblázat. Prímimplikáns-táblázat

\begin{tabular}{|l|c|c|c|c|c|}
\hline \multirow{2}{*}{ Prímimplikáns } & \multicolumn{5}{|c|}{ Primitív kifejezés } \\
\cline { 2 - 6 } & $T M E$ & $T M e$ & $T m e$ & $T m E$ & $t m E$ \\
\hline $\mathrm{T}$ & $\mathrm{x}$ & $\mathrm{x}$ & $\mathrm{x}$ & $\mathrm{x}$ & $\mathrm{x}$ \\
\hline $\mathrm{mE}$ & & & & $\mathrm{x}$ & $\mathrm{x}$ \\
\hline
\end{tabular}

A prímimplikáns-tábla létrehozásánál figyeltünk arra, hogy minden oszlop tartalmazzon legalább egy X jelölést. Azon kombinációk, amelyek oszlopában csak egyetlen X szerepel nem elhagyhatók, hiszen ezek a lényeges prímimplikánsok. Viszont a TmE oszlopa elhagyható anélkül, hogy a kifejezés értéke változna. A 3. táblázat alapján a minimalizált kifejezés, amelyre $\mathrm{Y}=1$ kimenet adódik $\mathrm{MV}=\mathrm{T}+\mathrm{mE}$, amely a következőképpen értelmezhető: Hatékony tanítási-tanulási folyamat akkor eredményezhető ( $\mathrm{Y}=1)$, ha a megfelelő térstrukturálás $(\mathrm{T})$ vagy nem kellőképpen átgondolt módszertani kultúra $(\mathrm{m})$ és széles eszközhasználat (E) jelenik meg a tanórán.

\section{Elméletgenerálás}

A tanulmány egyik kiemelt célja a csQCA elméletgenerálásra való felhasználása. Ehhez vissza kell térni az $\mathrm{MV}=\mathrm{T}+\mathrm{mE}$ minimalizált kifejezéshez. A logikai alapon létrehozott kifejezés valóban nem megszokott tételeket állít, de önmagában a megfelelő térstrukturálásnak, illetve a nem kellőképpen átgondolt módszertani kultúra és a széles eszközhasználat összekapcsolásának is lehetnek hatásai az eredményes tanítási-tanulási folyamatra. A tanulmány további részében a minimalizált formula megfelelő térstrukturálásra $(\mathrm{T})$ vonatkozó részét elemezzük, ennek ok-okozati kapcsolatrendszerének feltárására figyelünk (hasonlóan járhatunk el a formula másik részével is).

Az elméletgeneráláshoz vissza kell tekinteni a hipotetikus igazságtábla valós eseteire, azokon belül is a megvalósult térstrukturálást $(\mathrm{T}=1)$ generáló esetekre. A táblázat szerint ezek az 1., 3., 4. és 5. esetek, melyekhez összesen $\mathrm{N}=25$ napló tartozik. A kötetlen reflektív naplókat a MAXQDA szoftverrel elemeztük. A vizsgálat elején létrehozott főkategóriák további alkategóriákra bontását végeztük el, a kódolás az induktív logikai eljárás szerint zajlott. A fö- és alkategóriák képezte kódhierarchiát a MAXQDA MAXMaps funkciójával rendszereztük és illusztráltuk, amely így átláthatóvá tette a naplók (adott főkategóriára vonatkozó) belső strukturális rendszerét (2. ábra). 


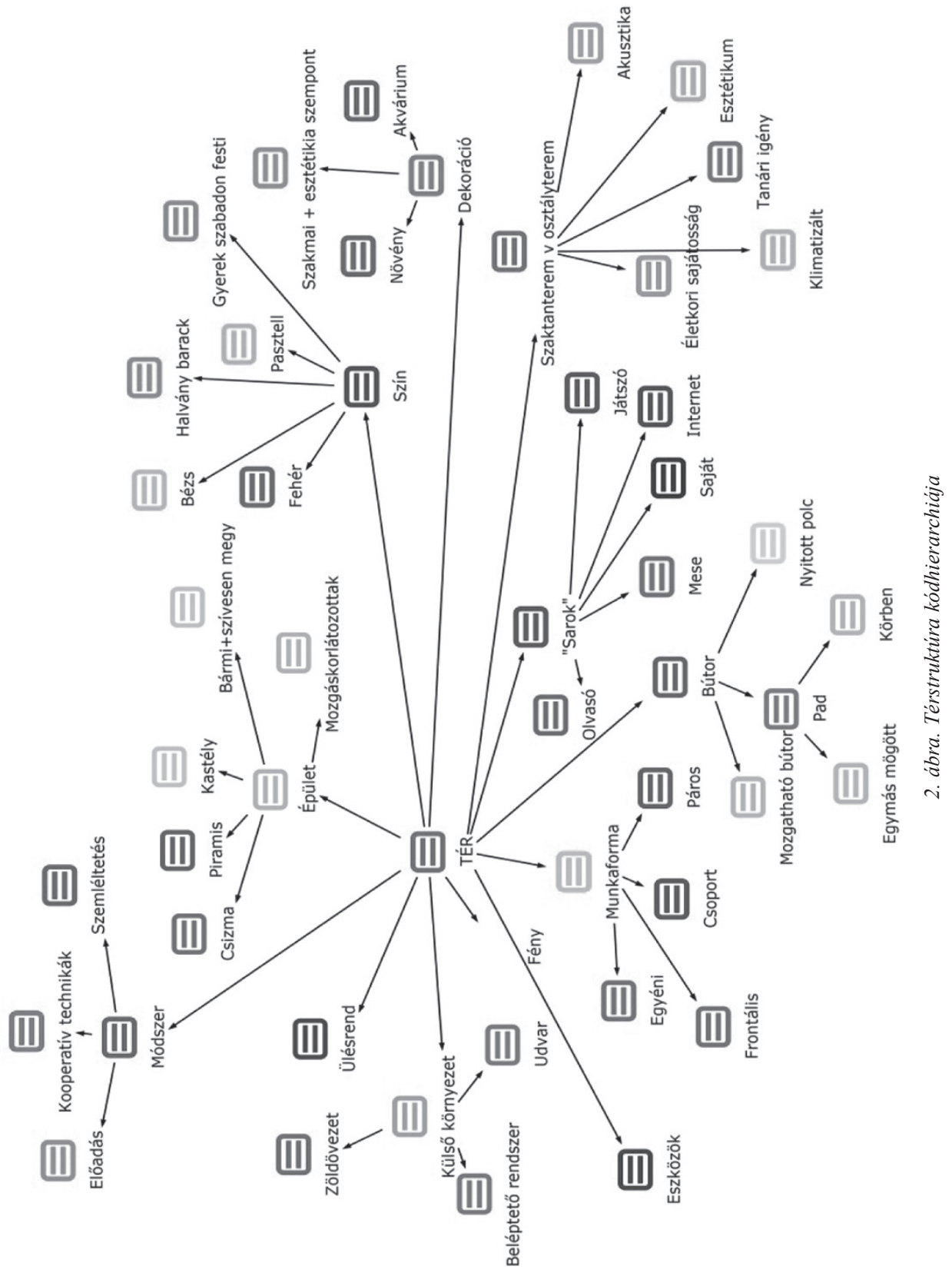


A kódhierarchia összetett struktúrát ábrázol, a fogalmak három szinten találhatók a hálózatban. Ha elfogadjuk azt, hogy a „Tér” fökategória a nulladik szinten szerepel, továbbá az első szinten találhatók azok a fogalmak, amelyek egy útvonalon érhetők

el a főkategóriától, akkor látható a három szint. Az első szinten 11 fogalom szerepel

Az iskola külsó környezetét és épületét tekintve találhatók futurisztikus vélemények is: "Iskola piramis alakú, kastély, csizmaforma, fekvó kutya, bármi, amibe a gyerekember szivesen bemegy.” Az intézmény „Gaudiféle hullámzó, folyamatosságot sugalló falstruktúrával rendelkezzen", ahol kitüntetett figye-

lem illeti a szineket, a fényt, hiszen mindez befolyásolja a tér érzékelését. Szinek tekintetében a naplók megosztottak, a fehértól (fehér azért, hogy „ne zavarják a tanulót a feladatra történó koncentrálásban") a színes falakig, valamint a semleges szinekig találhatók vélemények. Több helyen javaslatként szerepelt, hogy a tanulók szinezzék a falakat, hiszen igy közelebb kerülhetnek a saját tantermükhöz. A naplók kulcseleme a különbözó „Sarkak” iránti igény. Az olvasás, a játék, a mese mellett megjelenik az internet-sarok, valamint a saját igények szerint formált, berendezett „sarok”, ami természetesen a saját tér igényét jelenti. alkategóriaként, de a harmadik szinten is található 2 fogalom („Egymás mögött” és „Körben”). A fogalmak mögötti tartalmi elemek többnyire összhangot mutattak a naplók alapján, azaz a hallgatók nézetei közötti, az egyes tartalmi területekre vonatkozó markáns különbségek nem voltak. Az iskola külső környezetét és épületét tekintve találhatók futurisztikus vélemények is: „Iskola piramis alakú, kastély, csizma-forma, fekvő kutya, bármi, amibe a gyerekember szívesen bemegy.” Az intézmény „Gaudi-féle hullámzó, folyamatosságot sugalló falstruktúrával rendelkezzen", ahol kitüntetett figyelem illeti a színeket, a fényt, hiszen mindez befolyásolja a tér érzékelését. Színek tekintetében a naplók megosztottak, a fehértől (fehér azért, hogy „,ne zavarják a tanulót a feladatra történő koncentrálásban”) a színes falakig, valamint a semleges színekig találhatók vélemények. Több helyen javaslatként szerepelt, hogy a tanulók színezzék a falakat, hiszen így közelebb kerülhetnek a saját tantermükhöz. A naplók kulcseleme a különböző „Sarkak” iránti igény. Az olvasás, a játék, a mese mellett megjelenik az internet-sarok, valamint a saját igények szerint formált, berendezett „sarok”, ami természetesen a saját tér igényét jelenti. Mindez fontos, hiszen a pihenést, az órára való ráhangolódást segíti, meghatározó lehet a mindennapok iskolai világában. Olyan saját térről van szó, amely kellemes és biztonságot sugall az iskolában is, mindez szintén elengedhetetlen a hatékony iskolai munkához. A módszerek és munkaformák esetén a hallgatók a klasszikus (pl. szemléltetés) és újgenerációs (pl. kooperatív technikák) módszereket említették, valamint a négy munkaforma mindegyikét fontosnak tartják. A módszertani kultúrával összhangban az osztály (amely esztétikusan dekorált) térel-

rendezése is változik, mindezt a mozgatható bútorok, a körben, U-alakban elhelyezett egyszemélyes asztalok és saját szekrény teszi lehetővé. 


\section{Összegzés}

A hallgatói naplók komplex térszemléletről árulkodnak, az iskolai architektúra mellett az iskolai belső világ, a forma, a szín, a tárgyak, a belső tér egysége bontakozik ki. Nem szabad felednünk, hogy a térstruktúra hat az emberi viselkedésre, aktivitásra, tanulásra és tanítása egyaránt, bár kétségtelen, hogy sokunkban nehezen tudatosul hatásrendszere. A tér gondolatot ébreszt vagy gátol, maradásra késztet vagy elüz, harmóniát vagy káoszt generál, tevékenykedtet vagy passzív befogadásra kényszerít az iskolában. A tanulmányban minderre felhívtuk a figyelmet, rendszerezni és bővíteni kívántuk a pedagógiai terekkel kapcsolatos információinkat úgy, hogy közben a hazai pedagógiai kutatások terén egy új technika alkalmazhatóságára is rámutattunk.

\section{Irodalomjegyzék}

A tér diskurzusai. (é. n.) 2012. 06. 08-i megtekintés, h t t p ://g h t k. csik.s a pientia.ro/hu/ konferenciak/a-ter-diskurzusai/discourses-of-space

Barabási Albert-László (2008): Behálózva. A hálózatok új tudománya. Helikon Kiadó, Budapest.

Barabási Albert-László (2011): Villanások. A jövő kiszámitható. Nyitott Könyvmühely. Budapest.

Castells, M. (2005): A hálózati társadalom kialakulása. Az információ kora: gazdaság, társadalom és kultúra. I. Gondolat - Infonia, Budapest

Cisneros Puebla, C. A. (2008): Developing the convergence of CAQDAS and GIS. Elöadás: Software Development Seminar ATLASti 6 preview and the convergence of CAQDAS and GIS. University of Surrey UK, 12. november, 2008. 2013. 09. 16-i megtekintés, http://www.surrey.ac.uk/sociology/research/ researchcentres/caqdas/trainingandevents/oneday/ software_development_seminar_atlasti_6_preview_ and the convergence of caqdas and gis.htm

Döring, J. és Thielmann, T. (2008): Einleitung: Was lesen wir im Raume? Der Spatial Turn und das GeheimeWissen der Geographen. In: uők (szerk.): Spatial Turn. Das Raumparadigma in den Kulturund Sozialwissenschaften. Bielefeld. 7-45.

Géczi János (2010): Sajtó, kép, neveléstörténet. Iskolakultúra - Gondolat Kiadó, Veszprém-Budapest.

Goodchild, M., Anselin, L., Appelbaum, R. és Harthorn, B. (2000): Towards patially integrated social science. International Regional Science Rewiew, 23. sz. 139-159.

Hercz Mária és Sántha Kálmán (2009): Pedagógiai terek iskolai implementációja. Iskolakultúra, 19. 9. sz. 78-95.

Hermann, A. és Cronqvist, L. (2006): Contradictions in Qualitative Comparative Analysis (QCA): Ways Out of the Dilemma. European University Institute, Working Papers, Italy. 2014. 02. 06-i megtekintés, http://cadmus.eui.eu/bitstream/handle/1814/6305/ SP-2006-06.pdf? sequence $=3$
Jelich, F-J. és Kemnitz, H. (2003, szerk.): Die pädagogische Gestaltung des Raumes. Verlag Klinkhardt, Bad Heilbrunn.

Kárpáti Andrea, Szálas Tímea és Kuttner Ádám (2012): Közösségi média az oktatásban - Facebookesettanulmányok. Iskolakultúra, 22. 10. sz. 11-42.

Kemnitz, H. (2003): Pedagógiai architektúra. A pedagógiai terek kialakításának lehetőségei két iskola példája alapján. Magyar Pedagógia, 103. 1. sz. 119 128.

Lefebvre, H. (2006): Die Produktion des Raumes. In: Dünne, J. és Güzel, S. (szerk.): Raumtheorie, Grundlagentexte aus Philosophie und Kulturwissenschaften. Frankfurt am Main. 330-343.

Legewie, N. (2013): An Introduction to Applied Data Analysis with Qualitative Comparative Analysis (QCA). Forum Qualitative Sozialforschung / Forum Qualitative Social Research, 14. 3. sz. 2013. 12. 13-i megtekintés, http://nbn-resolving.de/ urn:nbn:de:0114-fqs1303154

Mayring, P. (2003): Qualitative Inhaltsanalyse. Grundlagen und Techniken. Beltz Verlag, WeinheimBasel.

Ollé János (2012): Virtuális környezet, virtuális oktatás. ELTE Eötvös Kiadó, Budapest.

Pléh Csaba (2014): Az ént körülvevő hálózatok meghatározói. Kognitív, evolúciós és szociálpszichológiai mozzanatok. In: Bárdos Jenő, Kis-Tóth Lajos és Racsko Réka (szerk.): Új kutatások a neveléstudományokban 2013. Líceum Kiadó, Eger. 193-205.

Poreisz Veronika (2013): Az objektív és szubjektív térérzékelés vizsgálatának lehetséges módszerei. In: Karlovitz János Tibor (szerk.): Ekonomické stúdie teória a praxis. 369-376. 2013. 09. 16-i megtekintés, www.irisro.org/gazdasagtan $2013 \mathrm{j}$ anuar/ G437PoreiszVeronika.pdf

Ragin, C. (1987): The Comparative Method. Moving Beyond Qualitative and Quantitative Strategies. Uni- 
versity of California Press, Berkeley - Los Angeles - London.

Rihoux, B., Rezsöhazy, I. és Bol, D. (2011): Qualitative Comparative Analysis (QCA) in Public Policy Analysis: an Extensive Review. German Policy Studies, 7. 3. sz. 9-82.

Sager, F. és Ledermann, S. (2013): Qualitative Comparative Analysis (QCA) und realistische Evaluation. Theoretische Parallelen und eine praktische Anwendung. 2013. 11. 20-i megtekintés, http://nbn-resolving.de/urn:nbn:de:0168ssoar-144025

Sanda István Dániel (2012): A pedagógiai tér minőségi dimenziói. Értelmezési lehetőségek - elmélet és gyakorlat. Képzés és Gyakorlat, 1-2. sz. 144-158.

Sánta Csaba (é. n.): Terünk titkai. 2013. 01. 02-i megtekintés, http://iqdepo.hu/dimenzio/14/14-02-03.html

Sántha Kálmán (2012): Geo-információk a kvalitatív pedagógiai vizsgálatokban. Iskolakultúra, 22. 11.sz. $57-65$.

Sántha Kálmán (2013): Multikódolt adatok kvalitatív elemzése. Eötvös József Könyvkiadó, Budapest.

Sántha Kálmán (2014): Qualitative Comparative Analysis: módszertani lehetőség a pedagógiai vizsgálatok számára. Iskolakultúra, 24. 6. sz. 3-16.

Schneider, C. O. és Wagemann, C. (2007): Qualitative Comparative Analysis (QCA) und Fuzzy Sets. Verlag Barbara Budrich, Opladen, Farmington Hills.
Stefer, C. (2011): Georeferenzierung und mögliche Einsatzfelder in qualitativer Sozialforschung. 2012. 09. 02-i megtekintés, http://www.MAXQDA.de/ download/Georeferenzierung.pdf

Takács Viola (2000): A Galois-gráfok pedagógiai alkalmazása. Iskolakultúra, Pécs.

Thiem, A. és Duşa, A. (2013): QCA: A Package for Qualitative Comparative Analysis. The R Journal, 5. 1. sz. 87-97. 2014. 01. 26-i megtekintés, http:// journal.r-project.org/archive/2013-1/thiem-dusa.pdf

Tóth Zoltán (2012): Alkalmazott tudástérelmélet. Gondolat Kiadó, Budapest.

Verd, J. M. és Porcel, S. (2012): An Application of Qualitative Geographic Information System (GIS) in the Field of Urban Sociology Using ATLAS.ti: Uses and Reflections. Forum Qualitative Sozialforschung / Forum Qualitative Social Research, 13. 2. sz. 2012. 06. 01-i megtekintés, http://nbn-resolving.de/ urn:nbn:de:0114-fqs1202144

Wendler, R., Bukvova, H. és Leupold, S. (2013): Qualitative Comparative Analysis in Information Systems and Wirtschaftsinformatik. 2013. 12. 11-i megtekintés, www.wi2013.de/proceedings/ wi2013\%20-\%20Track10-Wendler.pdf

Yates, S. (2010, szerk.): A tér költészete. Fotókritikai antológia. Typotex Kiadó, Budapest. 